\title{
John Y. Templeton III: Pioneer of modern cardiothoracic surgery.
}

Jing Li, B.S.

Thomas Jefferson University

Herbert E. Cohn, MD

Thomas Jefferson University

Charles J. Yeo, MD

Thomas Jefferson University

Scott W. Cowan, MD

Thomas Jefferson University

Follow this and additional works at: https://jdc.jefferson.edu/gibbonsocietyprofiles

Part of the History of Science, Technology, and Medicine Commons, and the Surgery Commons Let us know how access to this document benefits you

\section{Recommended Citation}

Li, B.S., Jing; Cohn, MD, Herbert E.; Yeo, MD, Charles J.; and Cowan, MD, Scott W., "John Y. Templeton III: Pioneer of modern cardiothoracic surgery." (2012). Department of Surgery Gibbon Society Historical Profiles. Paper 13.

https://jdc.jefferson.edu/gibbonsocietyprofiles/13

This Article is brought to you for free and open access by the Jefferson Digital Commons. The Jefferson Digital Commons is a service of Thomas Jefferson University's Center for Teaching and Learning (CTL). The Commons is a showcase for Jefferson books and journals, peer-reviewed scholarly publications, unique historical collections from the University archives, and teaching tools. The Jefferson Digital Commons allows researchers and interested readers anywhere in the world to learn about and keep up to date with Jefferson scholarship. This article has been accepted for inclusion in Department of Surgery Gibbon Society Historical Profiles by an authorized administrator of the Jefferson Digital Commons. For more information, please contact: JeffersonDigitalCommons@jefferson.edu. 


\title{
John Y. Templeton III: Pioneer of Modern Cardiothoracic Surgery
}

JING LI, B.S., HERBERT E. COHN, M.D., CHARLES J. YEO, M.D., SCOTT W. COWAN, M.D.

\author{
From the Department of Surgery, Jefferson Medical College, Thomas Jefferson University, Philadelphia, Pennsylvania
}

\begin{abstract}
John Young Templeton III was born in 1917 in Portsmouth, Virginia, and graduated from Jefferson Medical College in 1941. He completed his residency training under Dr. John H. Gibbon, Jr., and was the first resident who worked on Gibbon's heart-lung machine. After his training, he remained at Jefferson as an American Cancer Society fellow and Damon Runyon fellow and went on to become the fourth Samuel D. Gross Professor and Chair of the Department of Surgery in 1967. Dr. Templeton was the recipient of numerous grants and published over 80 papers in the field of cardiothoracic surgery. As a teacher and mentor, he was a beloved figure who placed great faith in his residents. He participated in over 60 professional societies, serving as president to many such as the Philadelphia Academy of Surgery and the Pennsylvania Association of Thoracic Surgery. He was also recognized through his many awards, in particular the John Y. Templeton III lectureship established in 1980 at Jefferson of whom Denton Cooley was the first lecturer. Dr. Templeton retired from practice in 1987. He is forever remembered as an important model of a modern surgeon evident in numerous academic achievements, the admiration and affection of his trainees, and the lives of patients that he had touched.
\end{abstract}

$T$ HE EARLY HALF of the 20th century was a dynamic time in cardiothoracic surgery. Brilliant minds of that era were pushing the field toward bold procedures that were both daring and life-saving. Many advancements were being made with the advent of World War II and the increased skill obtained in repairing complex diseases, skill that would soon be applied to valvular repairs and open heart surgery. It was during this time, armed with ingenuity and deftness, that John Y. Templeton III first ventured on the road to becoming a renowned cardiothoracic surgeon and a major contributor to the surgical community.

John Young Templeton III was born in 1917 in Portsmouth, Virginia, the oldest of four siblings. He completed his undergraduate studies at Davidson College in North Carolina in 1937. In 1941, he graduated from Jefferson Medical College as his father had in 1913 and his brother would in 1955 . He went on to serve in the Army Medical Corps in World War II after his internship year. In 1946, he returned to Jefferson to continue his residency training from 1946 to 1950 under Dr. John H. Gibbon, Jr. (Fig. 1) with whom he worked closely. He was the first resident who worked

Address correspondence and reprint requests to Scott W. Cowan, M.D., Department of Surgery, Thomas Jefferson University, 1100 Walnut Street, Suite 500, Philadelphia, PA 19107. E-mail: Scott. Cowan@jefferson.edu. on Dr. Gibbon's heart-lung machine, and he was present on May 6, 1953, to assist in the first operation that used this machine successfully to repair an atrial septal defect in an 18-year-old patient. He continued on after surgical residency at Jefferson as an American Cancer Society fellow and Damon Runyon fellow. ${ }^{1,3,4}$

In 1957, Dr. Templeton ascended to the rank of Professor at Jefferson, a role he served until 1964 when he was named Chief of Surgery at Pennsylvania Hospital and Professor at the University of Pennsylvania. Three years later he returned to Jefferson as the fourth Samuel D. Gross Professor and Chair of the Department of Surgery in 1967. During his short time as Chair (1967 to 1968), he showed great interest in the education of medical students and residents and enjoyed much approval. Unfortunately, as a result of the tragic accidental death of his son John, he stepped down in 1968 to devote more time to supporting his family, although he continued at Jefferson as a professor and an active cardiothoracic surgeon. ${ }^{1,4}$

During his distinguished career, Dr. Templeton was the recipient of numerous grants and published over 80 papers on topics ranging from metabolic acidosis in hypothermia to esophageal leiomyomas, and he held membership on the editorial boards of the American Practitioner and the Digest of Treatment. ${ }^{1,}{ }^{4}$ After he took on much of Dr. Gibbon's research in the 1950s, his apparent ingenuity was not limited to his publications. 


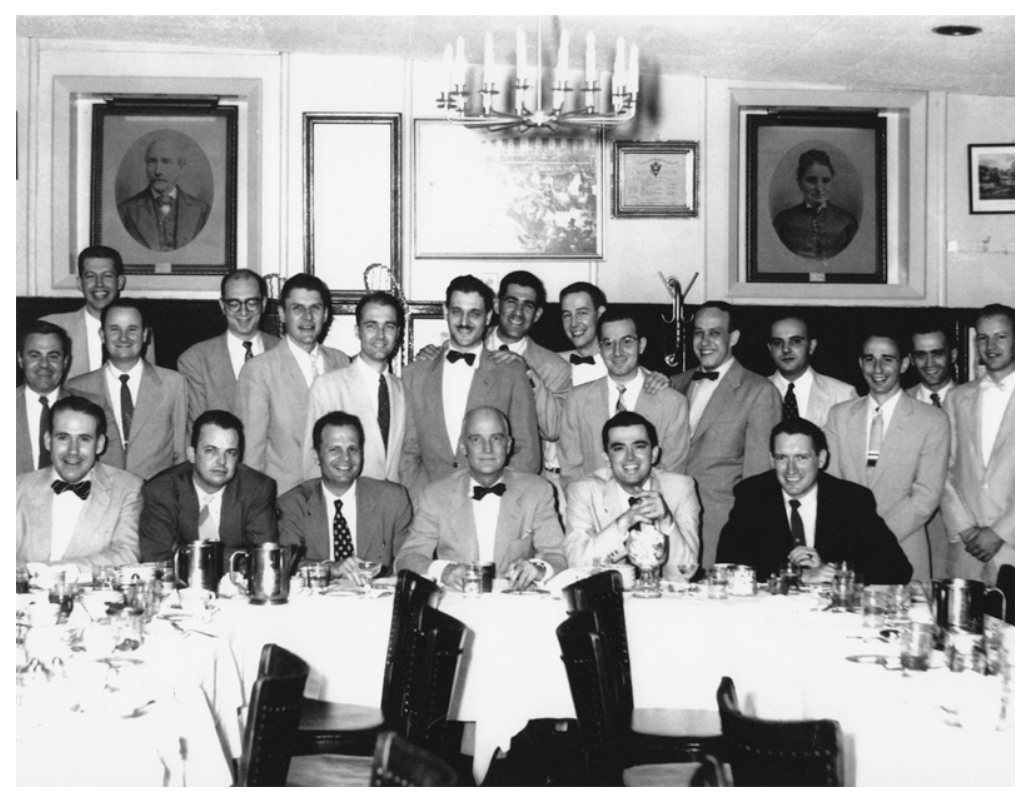

FIG. 1. The "Rib Crackers" Banquet in 1954 at the Franklin Inn. Dr. John Y. Templeton III (first row, second from the right) seated next to Dr. John $\mathrm{H}$. Gibbon, Jr. (first row, third from the right). Photograph courtesy of University Archives and Special Collections at Thomas Jefferson University.
As his contemporary, Denton Cooley (Fig. 2) noted in his case study in 1975 of a child who received an apicoaortic conduit for aortic stenosis, that Dr. Templeton was the first surgeon he knew by private correspondence who applied this experimental procedure clinically. He used this procedure successfully in five patients, one of whom lived 13 years postoperatively. ${ }^{2}$

Dr. Templeton was a beloved teacher and mentor to his students and residents. Numerous anecdotes from former pupils recall his impressive zeal for his work rivaled only by his love for hunting and fishing. His trainees still speak of his dexterity, composure, and humor in all his endeavors, chiding interns on their first day in the operating room that there was nothing in the human body that they could break that he could not fix. He placed great faith in his residents, often asking them to perform tasks that required innovative thinking such as finding the pressures across the aortic valve in the time before cardiac catheterization was commonly used.

An avid and enthusiastic member of the medical community, Dr. Templeton participated in over 60 professional societies, serving as President of the Philadelphia Academy of Surgery, Philadelphia County Medical Society, Pennsylvania Medical Society, Pennsylvania Association of Thoracic Surgery, Jefferson Alumni Association, and the Jefferson Medical Staff. He was Governor-at-Large of the American College of Surgeons and a member of the Board of Governors of the Heart Association of Southeastern Pennsylvania. Locally, he was a consultant to many hospitals in the surrounding areas outside of Philadelphia and in Delaware. A recipient of multiple awards such as the Golden Scalpel Award from the Division of Cardiothoracic Surgery, the Alumni Achievement

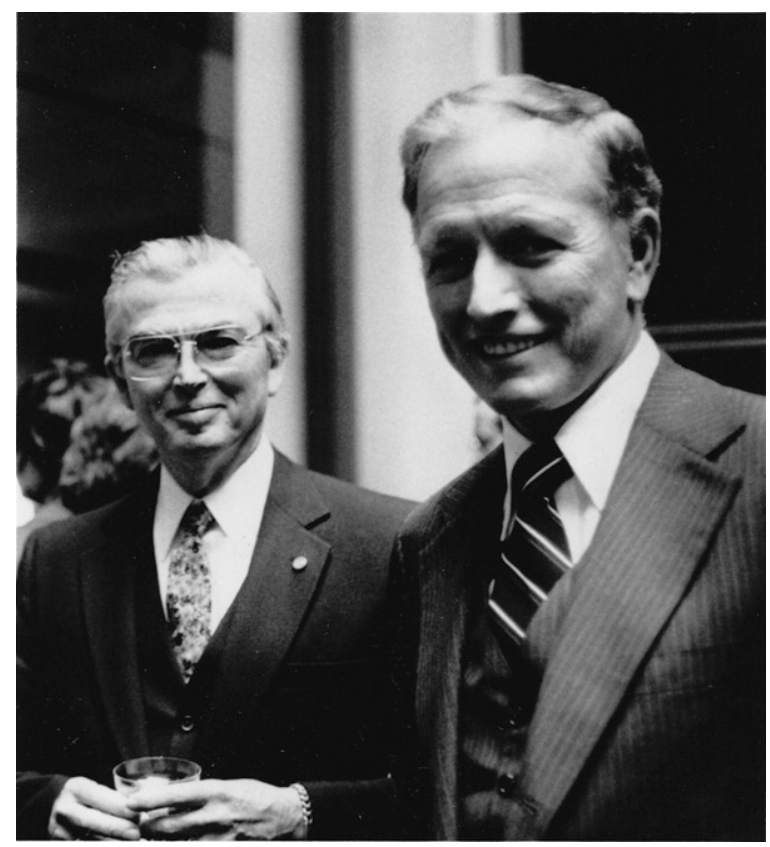

FIG. 2. Dr. John Y Templeton III (left) and Dr. Denton Cooley (right) in 1983 at Thomas Jefferson University's 30th anniversary celebration of the world's first successful open heart surgery using Gibbon's heart-lung machine. Photograph courtesy of University Archives and Special Collections at Thomas Jefferson University.

Award, and the Winged Ox Award, one of his greatest honors was the John Y. Templeton III lectureship established in 1980 by Dr. and Mrs. Benjamin Bacharach. The first lecturer was his friend and colleague, Dr. Cooley. He received an honorary doctor of science from Davidson College and doctor of laws from Jefferson in 1987, the year he retired from his practice at Jefferson. ${ }^{1,3,4}$ 
In his later years, Dr. Templeton continued his active lifestyle, pursuing his many outdoor hobbies. He eventually developed heart disease and underwent coronary bypass surgery performed by a former student. After his heart operation, he returned to hiking the Appalachian Trail, climbing Mount Katahdin, and building canoes at his cabin in Quebec. In 2007, 2 years after the death of Dorothy, his wife of 62 years, Dr. Templeton died from complications of congestive heart failure. ${ }^{3}$

As a recent figure in history, Dr. Templeton was the epitome of a modern surgeon. This was evident not only in his publications, awards, and leadership positions, but also in the more subtle ways that he touched each person whose path he had crossed. Undoubtedly, he saved the lives of innumerable patients, but it is the lessons to his students, who continue to practice and teach today, that allow his legacy to live on.

\section{REFERENCES}

1. Berkowitz JS. 'Adorn the Halls,' History of the Art Collection at Thomas Jefferson University. Philadelphia, PA: Thomas Jefferson University; 1999:500-1.

2. Cooley DA, Norman JC, Mullins CE, Grace RR. Left ventricle to abdominal aorta conduit for relief of aortic stenosis. Cardiovasc Dis 1975;2:376-83.

3. Downey SAJY. Templeton III, 89, medical pioneer. The Philadelphia Inquirer. April 2, 2007. Available at: http://articles. philly.com. August 18, 2011.

4. Resume, Faculty File: Templeton, JY, University Archives and Special Collections at Thomas Jefferson University. 